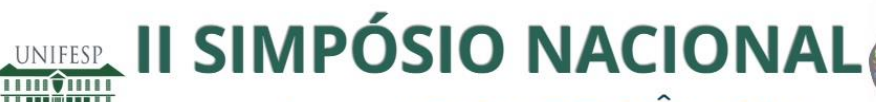

\title{
Aprendizagens e relações no tempo e espaço escolares: o ensino integral como espaço de prevenção à vulnerabilidade
}

\author{
Rafael Conde Barbosa \\ Faculdade do Educador \\ E-mail: conderafael26@gmail.com \\ Vera Maria Nigro de Souza Placco \\ Pontifícia Universidade Católica de São Paulo \\ Helena Lima \\ Pontifícia Universidade Católica de São Paulo
}

\section{Como citar:}

BARBOSA, Rafael Conde Barbosa; PLACCO, Vera Maria Nigro de Souza; LIMA, Helena. Aprendizagens e relações no tempo e espaço escolares: o ensino integral como espaço de prevenção à vulnerabilidade. In: SIMPÓSIO NACIONAL SOBRE ADOLESCÊNCIA: VULNERABILIDADE, PROTAGONISMOS E DESAFIOS, 2, 2016,

São Paulo. Anais...[S. I.]: 2016. p. 41-42.

DOI: http://dx.doi.org/10.22388/2525-5894.2016.020

A temática proposta pelo II Simpósio Nacional sobre Adolescência: Vulnerabilidades, Protagonismos e Desafios vincula-se, diretamente, à pesquisa de doutorado desenvolvida com os sujeitos que transitam na escola (discentes, docentes, coordenadores, gestores e outros funcionários) sobre o Programa Ensino Integral (PEI). O PEI tem como objetivo desenvolver crianças, adolescentes e jovens protagonistas que estejam aptos a compreender e atuar de forma clara e objetivo no meio social em que vivem. Foi objetivo nessa pesquisa conhecer que aprendizagens pessoais e relacionamentos esses sujeitos estabelecem na escola e quais ressignificações são desenvolvidas por eles, quanto aos espaços e os tempos escolares. $\mathrm{Na}$ tese, a hipótese era de que as relações potencializadas pelo PEI poderiam converter-se, ou estariam convertendo-se, em aprendizagens que colocam docentes, discentes e gestores como protagonistas de sua ação e de seus projetos de vida e que, se as condições materiais e imateriais oferecidas pela escola fossem seguidas de uma construção efetiva de uma proposta pedagógica, por todos os sujeitos, a escola de Ensino Integral poderia converter-se em um espaço no qual todos poderiam aprender, não só conteúdos curriculares, mas também a relacionar-se e a ressignificar o espaço escolar. O Programa desenvolve atividades focadas no protagonismo juvenil. Estas são desenvolvidas com a compreensão de que o jovem a ser formado deve ser autônomo, solidário e competente. Procedi a uma pesquisa qualitativa, com observações e entrevistas, em duas escolas públicas, uma de Ensino Fundamental - Anos Finais e outra de Ensino Médio. Participaram das entrevistas discentes, docentes, coordenadores gerais e de área, vicediretores, diretores e uma coordenadora da Secretaria de Educação do Estado de São Paulo. Os dados foram coletados nos anos de 2014 e 2015. As falas dos sujeitos foram analisadas e agrupadas de acordo com as similaridades que apresentaram, destacando-se aquilo de singular e próprio que esses sujeitos 
manifestaram em suas falas e em seu comportamento observado por mim, dando origem às seguintes categorias: a) Condições materiais e imateriais para a implementação do programa e b) Aprender e reaprender a interagir em diferentes níveis e a trabalhar no espaço escolar. Foram utilizados como referencial teórico os trabalhos de Teixeira (1959, 1962), Libâneo, Oliveira e Toschi (2012), Paro (1988a, 1988b, 2010, 2011), Cavaliere (2007), Imbernón (2010) e Dayrell (1996, 2012) - que pesquisam/pesquisaram as relações dentro de escolas com ensino regular e de escolas com programas ou projetos de educação integral -, dentre outros autores. As análises permitiram-me confirmar a hipótese inicial: que as relações desenvolvidas nas escolas participantes desta pesquisa convertem esses espaços em locais de trocas e de relações que, para além de conhecimentos curriculares, promovem aprendizagens que tornam esses sujeitos protagonistas de suas ações e de suas aprendizagens e construtores de seus projetos de vida. Esses alunos, ao serem convidados a participar da construção dessa nova escola, reconhecem-se como protagonistas e formadores, seja nos grupos de estudo que eles criam ou no momento em que são jovens acolhedores. Esse resgate do discente faz com que ele ressignifique essa escola e o seu papel como sujeito social capaz de transformar seu entorno e a si mesmo. Os docentes e a equipe gestora são comprometidos e entusiasmados com o trabalho desenvolvido. Esses profissionais aprendem a desenvolver um novo olhar para os alunos e isso é percebido por todos como extremante positivo. O PEI oferece suporte pedagógico nos momentos de formação continuada com o professor coordenador geral e com o professor coordenador de área. Esse comprometimento é reforçado e assumido por esses profissionais quando reconhecem a transformação no comportamento dos discentes, que se tornam mais cônscios de seu papel como alunos e proativos em relação à sua formação e ao cuidado com aqueles que chegam à escola, acolhendo e integrando os novos colegas ao programa numa perspectiva humanizada, consciente e com objetivo de construção coletiva de saberes.

Palavras-chave: Programa ensino integral (PEI). Educação integral. Escola de tempo integral (ETI). Política educacional. 